\title{
GAYA KEPEMIMPINAN DENGAN MOTIVASI KERJA PERAWAT DI RUMAH SAKIT JIWA
}

\author{
Putri Levina Maria de Haan \\ Hendro J.Bitjuni \\ Rina Kundre \\ Program Studi Ilmu Keperawatan Fakultas Kedokteran \\ Universitas Sam Ratulangi \\ Email : putribarail@gmail.com
}

\begin{abstract}
Motivation or encouragement in doing a job contributes to the work of nurses. Head room support and supervision of nurse work is needed to improve nurse performance. While organizational factors can also influence nurses' performance, one of which is about leadership, and to realize good performance, each of the leaders must have a leadership style. Leadership style is a behavior pattern designed to integrate organizational goals with individual goals, to achieve a goal. Research Design: This study researchers used a cross sectional design..The study was obtained using the chi square test and see the results of Pearson chi square with the help of a computer program producing a $p$ value of 0.000 ( $p$ $\leq 0.05)$. Conclusion: There is a relationship between leadership style and nurses work motivation at Prof.Dr. V.L Ratumbuysang
\end{abstract}

Keywords: Leadership Style, Nurses Work Motivation

Abstrak : Motivasi atau dorongan dalam melakukan suatu pekerjaan memiliki kontribusi terhadap kerja perawat. Dukungan dan supervisi kepala ruangan terhadap kerja perawat sangat dibutuhkan untuk meningkatkan kinerja perawat. Sedangkan faktor organisasi juga dapat berpengaruh dalam kinerja perawat, salah satunya adalahtentang kepemimpinan, dan untuk mewujudkan kinerja yang baik, masing-masing dari pemimpin harus memiliki gaya kepemimpinan. Gaya kepemimpinan adalah pola tingkah laku yang dirancang untuk mengintegrasikan tujuan organisasi dengan tujuan individu, untuk mencapai suatu tujuan. Desain Penelitian: Penelitian ini peneliti menggunakan desain cross sectional.Penelitian diperoleh dengan menggunakan uji chi square dan melihat hasil pearsonchi square dengan bantuan program komputer menghasilkan nilai $p 0,000(p \leq 0,05)$. Kesimpulan: Ada ubungan antara gaya kepemimpinan dengan motivasi kerja perawat di Rumah Sakit Jiwa Prof. Dr. V.LRatumbuysang.

Kata Kunci : Gaya Kepemimpinan, Motivasi Kerja perawat

\section{PENDAHULUAN}

Rumah Sakit adalah institusi pelayanan kesehatan yang menyelenggarakan pelayanan kesehatan perorangan secara paripurna yang menyediakan pelayanan rawat inap, rawat jalan, dan gawat darurat. Rumah sakit diselenggarakan berdasarkan pancasila dan di dasarkan pada nilai kemanusiaan, etika dan profesionalitas, manfaat, keadilan, persamaan hak dan anti diskriminasi, pemerataan, perlindungan dan keselamatan pasien, serta mempunyai fungsi sosial (UU No. 44 thn 2009 tentang Rumah Sakit).Disebuah organisasi fungsi dan peran pemimpin dalam mendorong pembentukan organisasi yang diharapkan manjadi dominan. Faktor kepemimpinan memegang peran penting dalam mempengaruhi bawahannya untuk menunjang tercapainya tujuan organisasi. Seorang pemimpin adalah orang - orang 
yang berada pada barisan depan dalam memperjuangkan perubahan. Pemimpin yang berhasil adalah pemimpin yang mampu mengelola atau mengatur organisasi secara efektif dan mampu melaksanakan kepemimpinan secaara efektif pula untuk tercapai tujuan organisasi (Siagian, 2003).

Perawat merupakan salah satu sumber daya manusia di rumah sakit yang menentukan penilaian terhadap kualitas pelayanan kesehatan. Hal ini wajar mengingat perawat adalah bagian dari tenaga para medik yang memberikan perawatan pada pasien secara langsung. Sehingga pelayanan keperawatan prima secara psikologis merupakan suatu yang harus dimiliki dan dikuasai oleh perawat (Nursalam, 2002). Berdasarkan data dari simk perawat jumlah perawat di Indonesia pada bulan oktober 2017 sebanyak 384.946 jiwa, sedangkan jumlah perawat di Sulawesi Utara berjumlah 904 jiwa (BPSSDM, 2016). Keberhasilan dalam pelayanan keperawatan sangat di tentukan oleh kinerja para perawat (Kuntoro, 2010). Jika kerja perawat buruk, maka keberhasian dan pelayanan keperawatan yang baik tidak dapat terpenuhi. Kinerja perawat harus didukung dengan diadakan kegiatan pembinaan dan pengembangaan yang pada akhirnya meningkatkan mutu pelayanan dari perawat. Kinerja individu dapat dipengaruhi oleh beberapa faktor antara lain faktor individu (pengetahuan, kemampuan, ketrampilan, latar belakang), faktor psikologis (persepsi, sikap, motivasi, dan kepribadian), dan faktor organisasi(sumber daya, kepemimpinan dan supervisi). Dan faktor psikologis sangat berpengaruh dalam kinerja perawat, salah satunya adalah motivasi. Motivasi atau dorongan dalam melakukan suatu pekerjaan memiliki kontribusi terhadap kerja perawat. Dukungan dan supervisi kepala ruangan terhadap kerja perawat sangat dibutuhkan untuk meningkatkan kinerja perawat (Abdullah komariah, 2012).

Faktor organisasi juga dapat berpengaruh dalam kinerja perawat, salah satunya adalah tentang kepemimpinan, dan untuk mewujudkan kinerja yang baik, masing-masing dari pemimpin harus memiliki gaya kepemimpinan.

Gaya kepemimpinan merupakan pola tingkah laku yang dirancang untuk mengintegrasikan tujuan organisasi dengan tujuan individu, untuk mencapai suatu tujuan (Suarli S. \& Bahtiar Y. 2012).Dari hasil penelitian Anastasia, di RSJ Menur Surabaya ditemukan bahwa salah satu masalah yang masih dihadapi di rumah sakit tersebut yaitu masalah oprasional yaitu masih memiliki kekurangan SDM terutama perawat dan dokter. Sebagian perawat di rumah sakit jiwa mengalami memiliki kecenderungan bekerja lebih santai dan waktu yang tersedia cukup banyak sehingga menjadikan mereka mengalami stress karena merasa dirinya menganggur. Perawat yang bertugas shift pagi-siang merasa santai pada pekerjaannya karena ada bantuan dari perawat yang sedang magang, namun pada pada perawat shift malam merasa kelelahan dengan jumlah perawat yang masih sedikit dan terkadang pasien mengalami gaduh gelisah ditengah malam, dari masalah yang terdapat di jurnal tersebut maka bisa disimpulkan bahwa perawat memiliki motivasi yang menurun (Anastasia, 2012).Studi pendahuluan yang dilakukan di rumah sakit Jiwa Prof. Dr. V.L Ratumbuysang didapatkan jumlah perawat yang ada di ruangan Maengket, Katrili, Alabadiri, Cakalele, Bunaken, Kabela dan Waraney adalah 89 perawat. Melalui hasil wawancara yang dilakukan oleh peneliti dengan 4 orang perawat pelaksana menyatakan bahwa sebagian besar kepala ruangan yang ada suka mengambil keputusan sendiri tanpa memusyawarahkan terlebih dahulu dengan bawahanya. Dan oleh peneliti didapatkan bahwa terdapat beberapa perawat yang mengalami penurunan motivasi karena disebabkan oleh stress kerja karena mengalami kejenuhan dan kelelahan karena pada saat shift pagisore para perawat merasa tidak terlalu 
banyak turun tangan karena rata-rata didapati bahwa pasien biasanya mengalami gangguan ditengah malam, dan biasanya perawat yang melakukan shift malam-pagi merasa kelelahan karena jumlah perawat yang melakukan dinas malam cenderung sedikit. Berdasarkan uraian di atas maka peneliti tertarik untuk meneliti dengan judul "Hubungan gaya kepemimpinan dengan motivasi kerja perawat di Rumah Sakit Jiwa Prof. Dr. V.L Ratumbuysang”.

\section{METODE PENELITIAN}

Penelitian ini peneliti menggunakan penelitian cross sectional. Cross sectional adalah penelitian yang mendesain pengumpulan datanya dilakukan pada saat titik waktu, fenomena yang diteliti adalah selama satu periode pengumpulan data, pada dasarnya variable dependen dan variabel independent dikumpulkan dan diukur pada waktu yang bersamaan (Swarjana,2012).Penelitian ini dilakukan di Rumah Sakit Jiwa Prof. V.L Ratumbuysang Manado. Penelitian ini dilakukan pada tanggal 11 mei 2019 jam 10 pagi. Penelitian ini menggunakan sampling purposivedengan jumlah perawat berjumah 69 orang. Kuesioner ini digunakan oleh Tifani Sydonia Paat dan Intan. Uji yang digunakan adalah uji statistik chi-square. Pengumpulan data menggunakan kuesioner dengan pertanyaan-pertanyaan terkait dengan tujuan penelitan. Instrumen penelitian adalah alat-alat yang digunakan untuk pengumpulan data (Notadmodjo, 2010).

Instrumen dalam lembar penelitian ini adalah kuesioner dan data demografi responden berupa nomor responden, nama responden, usia responden, jenis kelamin, pekerjaan dan pendidikan. Kuesioner yang digunakan merupakan kuesioner gaya kepemimpinan terdiri dari 20 item pertanyaan dengan empat pilihan jawaban terdiri dari pilihan jawaban A,B,C,D yang masing-masing jawaban akan mewakili gaya kepemimpinan. Kriteria objektif atau hasil ukur jika jumlah jawaban responden terbesar pada matriks G-1 adalah gaya otoriter, jumlah terbesar pada matriks G-2 adalah gaya demokratis, jumlah terbesar pada matriks G-3 adalah gaya partisipatif, dan G-4 adalah gaya liberal. Jadi yang dimaksud dengan matriks G-1,G-2.G-3, G4 adalah matriks G-1:kunci jawaban yang menunjukkan gaya kepemimpinan otoriter, matriks G-2:kunci jawaban yang menunjukkan gaya kepemimpinan demokratis, matriks G-3:kunci jawaban yang menunjukkan gaya kepemimpinan partisipatif, matriks G-4 : kunci jawaban yang menunjukkan gaya kepemimpinan liberal (Sydonia Paat, 2014)

Kuesioner yang digunakan untuk melihat motivasi kerja perawat terdiri dari 13 pertanyaan. Setiap jawaban diberi skor 1 menunjukkan jawaban ya dan 0 menunjukkan jawaban tidak. Rumah Sakit Jiwa Prof. V.L Ratumbuysang Manado merupakan wilayah peneitian untuk melakukan penelitian ini.Untuk memperoleh data tentang gaya kepemimpinan dengan motivasi kerja perawat yang ada Rumah Sakit Jiwa Prof. V.L Ratumbuysang maka peneliti mendatangi setiap ruangan keperawatan jiwa yang ada sesuai dengan jumlah responden yang sudah ditentukan (Intan, 2014)

Prosedur pengambilan data yang dilakukan adalah sebagai berikut: Editing: Untuk memeriksa data apa yang sudah sesuai dekapan dan kngan harapan serta memeriksa kelengkapan dan keseragaman data. Coding: untuk mempermudah pada saat analisis data dan juga mempercepat pada saat entry data. Processing: Dilakukan setelah seluruh variabel diberi kode. Data yang telah diberi kode kemudian dimasukkan terlebih dahulu dalam master table. Cleaning: Proses ini meyakinkan bahwa data yang telah dimasukkan betulbetul bersih dari kesalahan (Setiadi,2013). 
HASIL dan PEMBAHASAN

1. Karakteristik Responden

Tabel 1. Distribusi responden berdasarkan umur

\begin{tabular}{ccc}
\hline Umur & n & \% \\
\hline$\leq 25$ tahun & 9 & 13 \\
26-35 tahun & 26 & 37,7 \\
$36-45$ tahun & 20 & 29 \\
$46-55$ tahun & 9 & 13 \\
56-65 tahun & 5 & 7 \\
\hline Total & $\mathbf{6 9}$ & $\mathbf{1 0 0}$ \\
\hline
\end{tabular}

Tabel 1 menunjukkan umur responden paling banyak yakni umur 26-35 tahun yang berjumlah 26 responden sedangkan yang paling sedikit yakni 56-65 tahun yang berjumlah 5 responden.

Tabel 2. Distribusi responden berdasarkan jenis kelamin

\begin{tabular}{ccc}
\hline Jenis Kelamin & $\mathbf{n}$ & $\mathbf{\%}$ \\
\hline Laki-laki & 11 & 15,9 \\
Perempuan & 58 & 84,1 \\
\hline Total & $\mathbf{6 9}$ & $\mathbf{1 0 0}$ \\
\hline
\end{tabular}

Tabel 2menunjukkan mayoritas responden paling banyak yakni perempuan yang berjumlah 58 responden sedangkan yang paling sedikit yakni laki-laki yang berjumlah 11 responden.

Tabel 3. Distribusi responden berdasarkan tingkat pendidikan

\begin{tabular}{ccc}
\hline $\begin{array}{c}\text { Tingkat } \\
\text { Pendidikan }\end{array}$ & n & \% \\
\hline Ners & 23 & 33,3 \\
S1 Keperawatan & 26 & 37,7 \\
D3 Keperawatan & 20 & 29 \\
\hline Total & $\mathbf{6 9}$ & $\mathbf{1 0 0}$ \\
\hline
\end{tabular}

Tabel 3 menunjukan bahwa Tingkat pendidikan responden paling banyak yakni tingkat pendidikan S1 Keperawatan yang berjumlah 26 responden sedangkan yang paling sedikit yakni tingkat pendidikan D3 Keperawatan yang berjumlah 20 responden.
Tabel 4. Distribusi responden berdasarkan masa kerja

\begin{tabular}{ccc}
\hline Masa Kerja & n & \% \\
\hline Baru $(\leq 5$ & 22 & 31.9 \\
tahun $)$ & 26 & 37,7 \\
Sedang $(6-10$ & 21 & 30,4 \\
tahun $)$ & & \\
Lama $(\geq 10$ & & \\
tahun $)$ & & \\
\hline Total & $\mathbf{6 9}$ & $\mathbf{1 0 0}$ \\
\hline
\end{tabular}

Tabel 4menunjukkan responden paling banyak yakni pada masa kerja sedang (6-10 tahun) yang berjumlah 26 responden sedangkan yang paling sedikit yakni pada masa kerja lama ( $\geq 10$ tahun) yang berjumlah 21 responden.

\section{Analisis Univariat}

Tabel 5. Distribusi responden berdasarkan gaya kepemimpinan

\begin{tabular}{ccc}
\hline Gaya & $\mathbf{n}$ & $\mathbf{\%}$ \\
Kepemimpinan & & \\
\hline Otoriter & 6 & 8,7 \\
Demokratis & 18 & 26,1 \\
Partisipatif & 45 & 65,2 \\
Liberal & 0 & 0 \\
\hline Total & $\mathbf{6 9}$ & $\mathbf{1 0 0}$ \\
\hline
\end{tabular}

Tabel 5 menunjukkan gaya kepemimpinan yang tinggi terdapat pada gaya kepemimpinan partisipatif yang berjumlah 45 responden sedangkan yang paling sedikit yakni pada gaya kepemimpinan otoriter yang berjumlah 6 responden.

Tabel 6. Distribusi responden berdasarkan motivasi kerja perawat

\begin{tabular}{ccc}
\hline Motivasi Kerja & $\mathbf{n}$ & $\mathbf{\%}$ \\
\hline Tinggi & 63 & 91,3 \\
Rendah & 6 & 8,7 \\
\hline Total & $\mathbf{6 9}$ & $\mathbf{1 0 0}$ \\
\hline
\end{tabular}

Tabel 6 menunjukkan responden paling banyak yakni pada motivasi kerja tinggi yang berjumlah 63 responden sedangkan yang paling sedikit yakni pada motivasi kerja rendah yang berjumlah 6 responden 


\section{Analisis Bivariat}

Tabel 7. Hasil analisis Hubungan Gaya Kepemimpinan Dengan Motivasi Kerja Perawat Di Rumah Sakit Jiwa Prof. V.L Ratumbuysang Manado

\begin{tabular}{cccccccc}
\hline \multirow{2}{*}{$\begin{array}{c}\text { Gaya } \\
\text { Kepemimpinan }\end{array}$} & \multicolumn{6}{c}{ Motivasi } & \multirow{2}{*}{ Nilai P } \\
\cline { 2 - 7 } & Rendah & \multicolumn{2}{c}{ Tinggi } & \multicolumn{2}{c}{ Total } & \\
\cline { 2 - 7 } & $\mathrm{n}$ & $\%$ & $\mathrm{n}$ & $\%$ & $\mathrm{n}$ & $\%$ & \\
\hline Otoriter & 3 & 0,5 & 3 & 5,5 & 6 & 8,6 & \\
Demokratis & 2 & 1,6 & 16 & 16,4 & 18 & 26,0 & 0,000 \\
Partisipatif & 1 & 3,9 & 44 & 41,1 & 45 & 65,2 & \\
\hline Total & $\mathbf{6}$ & $\mathbf{6}$ & $\mathbf{6 3}$ & $\mathbf{6 3}$ & $\mathbf{6 9}$ & $\mathbf{1 0 0}$ & \\
\hline
\end{tabular}

Tabel 7 menunjukkan bahwa gaya kepemimpinan otoriter dengan motivasi rendah 3 responden $(0,5 \%)$, motivasi tinggi 3 responden $(5,5 \%)$. Gaya kepemimpinan demokratis dengan motivasi rendahponden $(1,6 \%)$ dan motivasi tinggi 16 responen $(16,4 \%)$. Gaya kepemimpinan partisipatif dengan motivasi rendah 1 responen $(3,9 \%)$ dan motivasi tinggi 44 responden $(41,1 \%)$. Hasil uji statistik diperoleh dengan menggunakan uji chi square dan melihat hasil pearson chi-square dengan bantuan program komputer menghasilkan nilai $p$ $0,000(p \leq 0,05)$ sehingga ada hubungan antara gaya kepemimpinan dengan motivasi kerja.

\section{Pembahasan}

\section{Gaya Kepemimpinan}

Hasil penelitian menunjukan gaya kepemimpinan di Rumah Sakit Jiwa Prof V.L.Ratumbuysang terdapat gaya kepemimpinan partisipatif dengan 45 responden, gaya kepemimpinan demokratis dengan 18 responden, dan gaya kpemimpinan otoriter dengan 6 responden. Kepala ruangan di Rumah Sakit Jiwa Prof.V.L Ratumbuisang sebagian besar mempunyai gaya partisipatif karena dari hasil penelitian didapatkan bahwa sebagian besar kepala ruangan dapat mengambil sebuah keputusan dengan cara membicarakan masalahnya kepada para perawat, kemudian meminta pendapat dari para perawat dan langsung membuat keputusan. Hal ini sesuai dengan pengertian gaya gaya kepemimpinan partisipatif yang merupakan gabungan bersama antara gaya kepemimpinan otoriter dan demoratis dengan cara mengajukan masalah dan mengusulkan tindakan pemecahanya kemudian mengundang kritikan, usul dan saran bawahan. Dengan mempertimbangkan masukan tersebut pimpinan selanjutkan menetapkan keputusan final tentang apa yang harus dilakukan bawahannya untuk memecahkan masalah yang ada. Gaya ini, dapat memudahkan seseorang pemimpin dalam mengambil keputusan karena tidak sematamata hanya demi kepentingan individual saja namun dapat mencakup kepentingan kelompok (Maria, 2017).

\section{Motivasi Kerja}

Hasil penelitian di Rumah Sakit Jiwa Prof V.L.Ratumbuysang menunjukkan motivasi kerja tinggi dengan 63 responden dan motivasi kerja rendah 6 responden, dari hasil penelitian yang didapati oleh peneliti sebagian besar perawat memiliki motivasi kerja yang tinggi karena didapati sebagian besar perawat memiliki komunikasi yang baik dengan kepala ruangan dan kerja sama tim yang baik dengan sejawat yaitu memiliki hubungan yang harmonis antar sesama perawat, dan sebagian besar perawat sering mendapat penghargaan atas prestasi kerja yang didapatkan sehingga kedua hal tersebut dapat membuat perawat di rumah sakit tersebut memiliki motivasi kerja yang tinggi. Hal ini menunjukkan bahwa sebagian besar perawat yang memiliki motivasi kerja yang tinggi dapat menimbulkan hasil kinerja yang baik (Nazvia Nastasia, 2014)

Motivasi merupakan masalah kompleks dalam organisasi, karena kebutuhan dan keinginana setiap anggota organisasi. Setiap anggota organisasi bersifat untik secara biologis dan psikologis, serta berkembang atas dasar proses belajar yang berbeda pula. Keadaan kejiwaan dan sikap mental manusia yang dapat mendorong untuk melakuakan suatu kegiatan atau gerakan dan mengarah 
kepada suatu perilaku kearah tercapainya kebutuhan yang memberikan kepuasan atau mengurangu ketidakaseimbangan. Kebutuhan tersebut dapat bersikap fisikbiologis social-psikis, misalnya keakraban, penghargaan, pengakuan keamanan, keselamatan, perlindungan, kepastian, jaminan social, dan sebagainya. Motivasi atau motif adalah suatu dorongan dari dalam diri seseorang yang menyebabkan orang tersebut melakukan kegiatan-kegiatan tertentu guna mencapai suatu tujuan. Manfaat motivasi yang utama adalah menciptakan gairah kerja, sehingga produktivitas tenaga kerja meningkat, sementara itu, manfaat yang diperoleh karena bekerja dengan orangorang yang termotivasi adalah pekerjaan dapat diselesaikan dengan tepat.Artinya pekerjaan diselesaikan sesuai standar yang benar dan dalam skala waktu yang sudah ditentukan.Serta orang senang melakukan pekerjaannya.

Pekerjaan yang dikerjakan akan membuat orang senang mengerjakannya. Orang pun akan merasa dihargai/ diakui, hal ini terjadi karena pekerjaannya itu betul betul berharga bagi orang yang termotivasi, sehingga dia berkerja keras. Hal tersebut dapat dimaklumi, karena dorongan yang begitu tinggi berhasil mencapai target yang mereka tetapkan. Kinerjanya akan dipantau oleh individu yang bersangkutan dan tidak membutuhkan terlalu banyak pengawasan serta semangat juangnya akan tinggi (Handoko, 2007)

\section{Hubungan Gaya Kepemimpinan Dengan Motivasi Kerja Perawat}

Hasil penelitian menunjukkan gaya kepemimpinan partisipatif dengan motivasi rendah sebanyak 1 responden $(3,9 \%)$, tapi ada juga motivasi yang tinggi sebanyak 44 responden $(41,1 \%)$. Untuk gaya kepemimpinan demokratis memiliki motivasi yang rendah yakni 2 responden (1,6\%), dan motivasi tinggi yakni 16 responden $(16,4 \%)$.
Gaya kepemimpinan otoriter yang memiliki motivasi rendah yakni 3 responden $(0,5 \%)$ dan motivasi tinggi yakni 3 responden $(5,5 \%)$. Berdasarkan hasil uji statistik dengan menggunakan uji chi square diperoleh $P$ value sebesar $0,000<0,005(P=0,000 \leq \alpha)$ yang berarti bahwa ada hubungan yang signifikan antara gaya kepemimpinan dengan motivasi kerja perawat di Rumah Sakit Jiwa Prof.V.L.Ratumbuysang Manado.

Berdasarkan data diatas dapat diketahui bahwa gaya kepemimpinan seorang kepala ruangan dapat mempengaruhi motivasi kerja perawat. Sesuai dengan penelitian Nurfadillah (2013), bahwa adanya hubungan yang bermakna antara gaya kepemimpinan dengan motivasi kerja perawat, yakni dalam hal ini dapat disimpulkan bahwa gaya kepemimpinan partisipatif menghasilkan motivasi kerja perawat yang tinggi.

\section{SIMPULAN}

Berdasarkan hasil penelitian kepada perawat di Rumah Sakit Jiwa Prof.V.L.Ratumbuysang Manado ditarik kesimpulan yaitu gaya kepemimpinan kepala ruangan merupakan gaya kepemimpinan partisipatif dan motivasi kerja perawat yang paling banyak ditemukan adalah motivasi kerja tinggi dan terdapat ada hubungan gaya kepemimpinan dengan motivasi kerja perawat.

\section{DAFTAR PUSTAKA}

Abdullah, K., Sidin, A. I., \& Pasinringi, S. A. 2014. Hubungan pengetahuan, motivasi dan supervisi dengan kinerja pencegahan infeksi nosokomial di RSUD Haji Makasar. (vol:3 no:1) (hal:3)

BPPSDM Kesehatan Kementerian Kesehatan Republik Indonesia http://bppsdmk.kemkes.go.id/info_sdmk/ info/rekap kab?kab=7171\&rumpun $=$ Diakses : mei, pukul 17:00 WITA. 
Handoko, T.Hani. 2007. Manajemen Sumber daya Manusia, BPFE.Yogyakarta (hal:22)

Intan, 2014. Hubungan Antara Karakteristik Demografi Dan Motivasi Kerja Dengan Kinerja Perawat Di Runkitalc dr. Wahyu Slamet Bitung (skripsi hal:69)

Kuntoro, A. 2010. Buku Ajar Manajemen Keperawatan. Nuhu Medika.Yogyakarta (hal:30)

Maria, 2017. Manejemen Keperawatan : Konsep Dan Aplikasi Dalam Praktik Keperawatan Profesional. Yogyakarta : Pustaka Baru Press (hal:17)

Nastasia,N. 2014. Faktor yang Mempengaruhi Kepatuhan Pelaksanaan SOP Asuhan Keperawatan di ICU-ICCU RSUD Gambiran Kota Kediri (volume:28 no:1) (hal:2)

Notoatmodjo, S . 2010. Metodologi

Penelitian Kesehatan. Jakarta.

Rineke Cipta. (hal:150)

Nurfadillah, N. 2013. Hubungan

Gaya Kepemimpinan Kepala Ruangan Dengan Motivasi Kerja Perawat di Ruang Perawatan RSUD Syekh Yusuf Kab. Gowa (Doctoral dissertation, Universitas Islam Negeri Alauddin Makassar) (volume:2 no:1) (hal:3)
Nursalam 2002. Manajemen Keperawatan: Aplikasi dalam Praktik Keperawatan Profesional Edisi. Jakarta : Salemba Medika (hal:38)

Paat, S. T., Robot, F., \& Lolong, J. 2014. Hubungan Antara Gaya Kepemimpinan Dengan Pendokumentasian Asuhan Keperawatan Di Instalasi Rawat Inap C Rsup Prof. Dr. RD Kandou Manado. Jurnal Keperawatan (skripsi hal:58)

Setiadi. 2013. Konsep dan PraktekPenulisan Riset Keperawatan. Ed 2. Yogyakarta. Graha Ilmu (hlmn:40)

Siagian P. S, 2003. Teori Dan Praktek Kepemimpinan, pt. Rineka Cipta Jakarta (hal:19)

Suarli S. \& Bahtiar Y. (2012). Manajemen keperawatan dengan pendekatan praktis. Jakarta: Erlangga. (hal:28)

Susiani Anastasia.N dan Andrian Marselius.2012. Studi Deskriptif Burn Out dan Coping Stres Pada Perawat di Ruang Rawat Inap Rumah Sakit Jiwa Menur Surabaya (vol:1 no:1) (hal:2)

Swarjana, Ketut. 2012. Metodologi Penelitian Kesehatan. Yogyakarta: Andi (hal:37)

Undang-undang Republik IndonesiaNomor 44 tahun 2009 Tentang Rumah Sakit 